\author{
Наталія Хібеба \\ Львівський національний університет \\ імені Івана Франка \\ ORCID: 0000-0003-1098-3082; e-mail: khibeba@ukr.net
}

\title{
Слово коровай: діалектний текст та обрядовий контекст
}

\begin{abstract}
Реферат: Записані під час експедицій на Бойківщину впродовж 1999-2016 років тексти про весілля, доступні діалектні, фольклорні, етнографічні записи від кінця XIX ст. свідчать, що до $50-$ х років XX століття 3 обрядовою метою використовували не коровай, а випечений домашній хліб із житньої чи вівсяної муки, згодом - із пшеничного борошна або ж куплений виріб.

Сучасні тексти про бойківське весілля дають змогу проілюструвати функціювання слова коровай. Проаналізовано семантику лексеми, іiі здатність утворювати деривати 3 обрядовим значенням, тенденцію до компонування сталих словосполучень, а також обрядовий контекст використання короваю. Лексема демонструє варіативність на фонетичному, акцентуаційному, словотвірному рівнях. Відзначено різні назви на позначення оздоб на короваю, зокрема спеціально випечених із тіста виробів. У статті наведено розповіді респондентів про вірування, ворожіння тощо, пов'язані 3 випіканням короваю.
\end{abstract}

Ключові слова: лексема, весільна лексика, номінація, бойківські говірки

Abstract: The word korovay: a dialectal text and the ritual context. Texts about weddings, recorded during expeditions to Boykivshchyna in 1999-2016 and comprising dialectal, folklore and ethnographic records from the late $19^{\text {th }}$ century, are evidence that until the $1950 \mathrm{~s}$, it was not the korovay but cooked, homemade bread made from rye or oat flour (later on from wheat flour) that was used to prepare a ceremonial product. Modern texts about Boykos' weddings provide information about the word korovay. In this article, the semantics of the lexeme, its ability to form derivatives indicating ceremonial aspects, a tendency to form stable phrases, as well as the ritual context of the use of the word korovay are analysed. The lexeme demonstrates variability on the level of phonetics, accent and morphology. Various names have been used to denote decorative korovays, including specially baked products.

In the article, the respondents talk about their beliefs and the divinations revolving around the process of baking bread.

Key words: lexeme, wedding vocabulary, nomination, Boyko dialects

Серед обрядових атрибутів головний весільний хліб - коровай - вирізняться багатофункційним та символічним використанням на різних етапах обряду: під час сватання, барвінкових обрядодій, благословення наречених на подружнє життя, обдаровування наречених, розподілу між гостями в обряді «перепою» чи у повесільний день та ін. 
Записані під час експедицій на Бойківщину впродовж 1999-2016 років тексти про весілля (див.: Мережа обстежених населених пунктів), доступні діалектні, фольклорні, етнографічні записи від кінця ХІХ ст. свідчать, що до 50-х років XX століття 3 обрядовою метою використовували не коровай, а випечений домашній хліб із житньої чи вівсяної муки, згодом - із пшеничного борошна або ж куплений виріб (дет. див: Хібеба 2018а; про назви весільного печива див. також: Хібеба $2018 b)$. Зокрема на Турківщині в I пол. XX ст., як зафіксував В. Кобільник, короваєм називали домашній хліб, який спеціально випікали значно більшим за інші хліби: „На кілька днів перед весіллям приготовляють їду. Печуть більше хліба, до 50 бохонців. Весільного тіста не солять. Роблять один бохонок хліба значно більший, званий «коровай». Печуть його вечір перед шлюбом, і дружба всаджує його на лопаті до печі. Під час весілля май цей хліб своє спеціальне призначення" (Кобільник 2009, 250). 3. Кузеля, описуючи весільний обряд на Стрийщині, також відзначив: „Короваю тут не печуть зовсїм, а короваєм називають хлїб, який купують у містї. «Корогвай» цїлком чистий, з разової муки: церемоній при печенню нема жодних, бо печуть його враз з иньшими хлїбами на весїлє” (Кузеля 1908, 129).

Респонденти старшого віку короваєм називають буденний домашній хліб, здебільшого неоздоблений, який використовували під час весілля: буў mo'д'i хл'iб / mи'пер 'кажут короввай (НГс); Ізараз ўже кара'вал'і прийили / то печут ка-

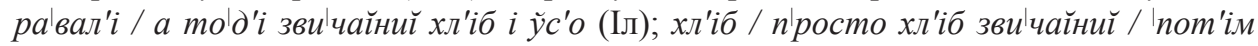
корогьвай пек'ли (Кр); хто там знаў коровайі 'ран'ше / два хл'іби к'ругл'i спечут ma $\breve{l}$ y̆c'o (Уp); пор.: літ. корова́й 'великий пухкий хліб із прикрасами, який печуть на весілля' (СУМ, IV, 295).

I. Шевчик-Лукавиченко зазначив: „Бойки або «гірняки», як себе зовуть, це вбогий нарід, прибитий тьмою віків, котрий ціле життя не їсть пшеничного хліба, хиба на «річні» великі свята зїсть «гуску» (булка) або «паску» (пасха) з купчої муки, нарід, що не знає «благодати» природи, що на своїх плечах обірник на гори виносити мусить, щоб у зимі зїсти вівсяного «опалянка», колючого і гіркого, як його життя" (Мисевич 1937, 59).

Сучасні респонденти пояснюють відсутність у ті часи короваю - випеченого весільного хліба 3 прикрасами - тогочасною бідністю, зумовлену низькою врожайністю сільськогосподарських культур, здебільшого жита та вівса, через особливості природного ландшафту Бойківщини: ко лис' |paн'че $i$ коро'вай не пек'ли / ше за 'того / аш ти'пер'ка ўже / ууже йак буў калгосп // а 'ран'че / 'заки ше 'мойа

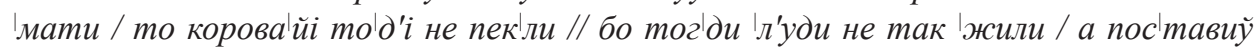

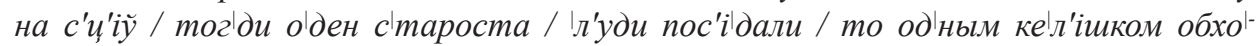

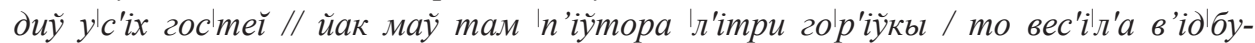

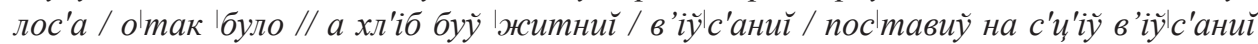
хл'іб $i$ ๖жтний $i$ с'тароста покрайаў по кусккови / по кусккови $i$ то // а так не 'било та'кого 'йід'ін'а / йак Ізараз / шо ми понаклладуйем по сто л'i / усс'о / сттоли

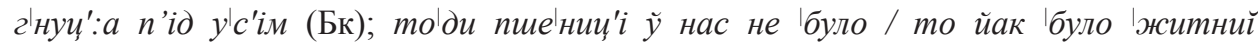
хл'іб / то пек'ли 'житний // [...] а ти'пер' йе коро вай / так / 'торти / ma|к'е ўс'аке // а Ізараз то не то / шо 'було ко лис' (Лб); - А коровай? - бу|ло аши n'iз|н'іше // спек'ли х'л'іба уу с'войім печчи і уус'о // пос'тавили по д'войе на 'купу / так покрайали / на'р'ізали / та йой! // не бу'ло 'ничо (Лс); спек'ли св'ій хл'іб / коро'вайу не 


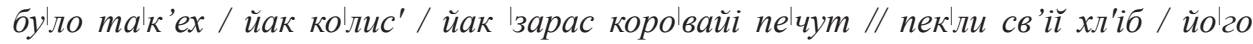
красно ўбрали той хл'іб / та й с хاл'ібом ішыли // а'би хл'іб буў // хто коллис знаў

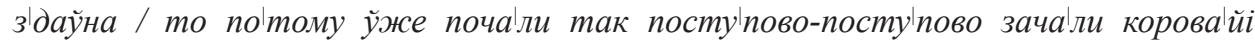
ве лик'i (Мл).

У сучасних бойківських говірках лексема коровай демонструє варіативність

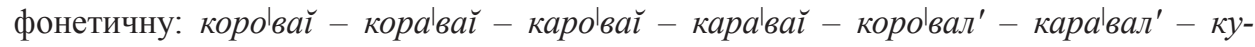
pу'вай; акцентуаційну: кара'ва'л'i, коро'ва'йi; словотвірну: корог'вайец' - корог'вайчик.

На підставі аналізу текстів про бойківське весілля окреслено семантичну структуру слова коровай, яку формують такі компоненти:

- 'обрядовий хліб нареченого, який наречений чи його гості приносили до нареченої':

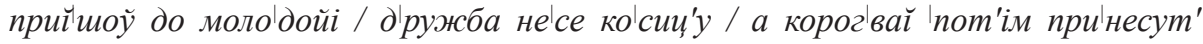
с'вах'и (Бг); 'зараз вес'іл'а Іразом // йак окремо / то печут два коровайі // прихход'ат 'гос'm'i до молодойі і при'нос'ат коро вай / а по тому об|м'ін'уйут / той лицшайут з рушни'ком / а той заби'райут // а йакщо |разом / то о дин коро'вай // і'дут до 'росписки / с'тел'ут руш'ник 'вишитий / рушни'кы / n’im коро'вай руш'ник крассівиц несут (Бк); во'ни прийџ'ли 'перед 'хатоў / то с'тароста виходиу

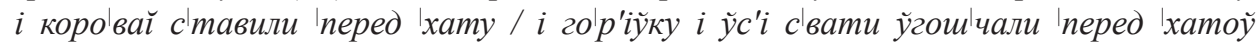

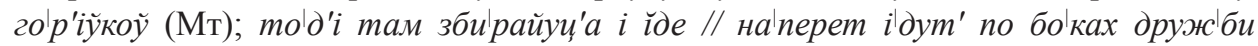
i молодий / наңперет йде музика / йде сlтароста с коровайем / йутт там m'i ку'харки / m'i с'вашки / йак ви 'кажете / з го р'ілкойу / з:а'кускойу / сn 'iो вайут' / nрис'n'івуйут' (Лс); йак моло дий йоуй до моло дойі / то н'іс коро вай // ну / а по 'тому моло да йе до моло дого / тиш коров вай бе ре / ве лик’i корова йі (Pc); буў короввай

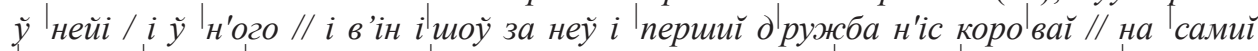

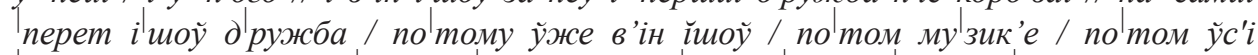
|л'уде // в'ін н'іс коро вай до |нейі / i заби литай там (Лб); молодий йак йшоў за молодоў / несли корофвай / корофвайнчка несла коро'вай // i там корофвай ўже личмали / не брали той короввай (Вч);

- 'обрядовий хліб, який клали на стіл, коли весільні гості нареченої перегороджували дорогу весільним гостям нареченого':

перего|роджуйут / перего роджували 'ран'че $i$ Ізараз // клаудут там сm'ï̌ / на сто'л'і шо там / карафвай сто'йіт на сто'л'і (Лб);

- 'обрядовий хліб, із яким танцювала коровайничка ('жінка, яка на голові несла коровай'), вимагаючи викупу':

коро вай то буў так // коровай спеклли / на коровайі / той корофвай намайели / $i$ йак йлл молодий за молодоу / несла корофвайничка на голоф'’ корофвай до молодойі // там коровай кілали на с'm'ï̆ $i$ короввайнчка запла'т'іт ми // с тим коровациом гу'л'ала на под'в’ірйу коровайнчка с коровациом на голо'в'i / на голо'в'i дерџжала і гу|л'ала з дружбоў // д|ружба дерџжаў / би не ў|пала коро'вайника / бо

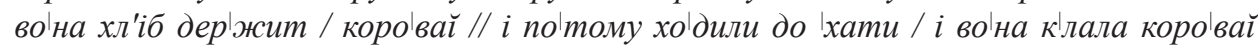
на с'm'iў / і пла'тили / купу'вали (Вч);

- 'обрядовий хліб, яким батьки благословляли наречених':

по'тому заходдил благосло'вити // та'кож вер'талис'а до 'хати усс'а родина /

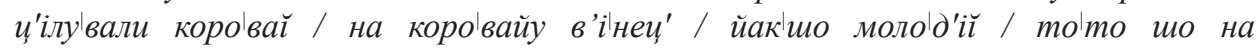
Іголову (Лб); 


\section{- 'хліб, який приносили до церкви й залишали його священикові після шлюбу':}

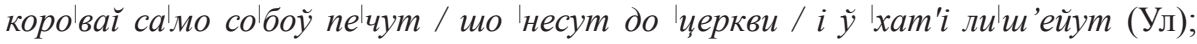

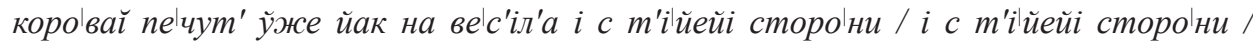
два коровайі // молодий йе с коровайем до молофойі // а у моло дойі теж печут'

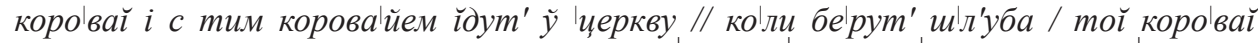
молофдойі ли'шайуm' у 'церкв'i (Рп); та кора вай пек'ли // ўби рали той коро вай так 'файно ўс'акими к' '’тами // ' 'тароста на рушни ку н'іс до 'иеркви // руш'ник

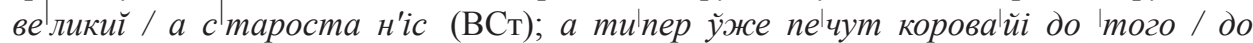
'иеркви // йак і'дут до с'л'убу / то йде $і$ коро вай не се с'тароста йі'ден коро'вай /

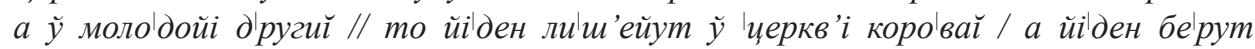
забирайут ўже йак йдут іс ш'л'убу до молодойі чи до молофого / то нессут

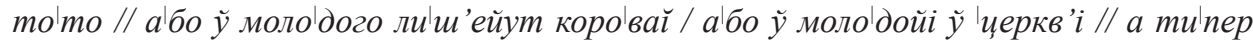
так (Дб); $\check{y}{ }^{\mid}{ }^{\prime}$ 'ого с староста / $i \check{y}{ }^{\mid}$нейі // не сут два короввайі до 'иеркви / рушни'к'i

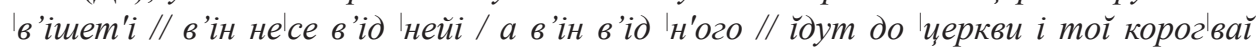
сттайл'ат на с'толик (Ям); mреба гти с коро'вайом до 'иеркви / йі ден 'несут Іперед молодойі (Тр); короввац те|пер |несут до 'черкви / короввай несут до

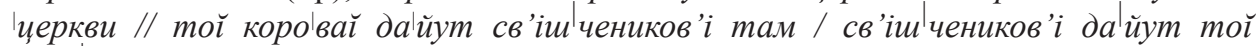
коровай (Pc); уоже зби'райуй':i до ш'л'убу / i с корогвацйами так 'само йдут до циеркви (СНб);

- 'обрядовий хліб із запханими грошима, які мала знайти наречена' (ці гроші, за бойківським звичаєм, наречена витягала зубами)':

принесли коро'вай / mo'той коро'вай половину ли'шали ў молодойі / а поло вину завер тали до с'войіх л'удец // перекрайували наполовину той корофвай / $i$ ше

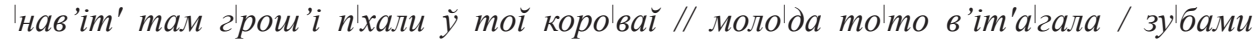
вит'агала / бо так 'сил'но пххали г'рош'i / шо вонна не могла // поттому то'то перекрайували / половину брай сытароста с:обоў до с'войіх л'удей / тих / шо

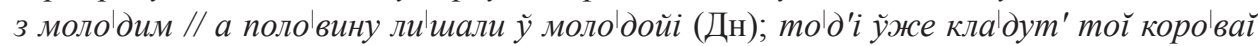

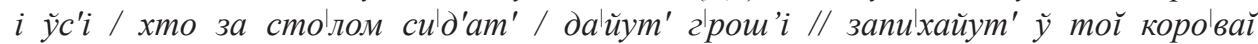
$i{ }^{\prime}$ пот'ім / йак при'нос'ат' до молодойі / то молода иеей короввай розбифрайе $i$ m'i г'ром'i забирайе (Рп);

\section{«пропою»': \\ - 'обрядовий хліб, призначений для розподілу між гостями в обряді}

а короввай пек'ли той / шо 'р'ізали у ве'ликому 'тан'u’'y / mo |того корова йа 'p'iзали / розу|м'ійете // - А що таке великий танець? - велликий 'танеи' / то 'кожнии

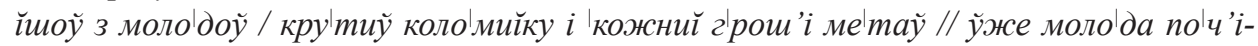

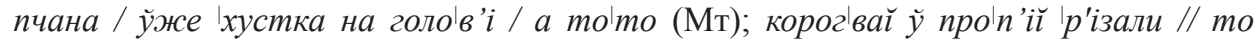
'були ў корогвацйу три 'йай'і 'мали 'бути / то ўже д|ружба маў шу|кати то'т'i 'йайи'i // а корог'вай |р'ізали на кусіки та роздаввали усс'ім Ігос'm'ам (Бг); тогыди йак

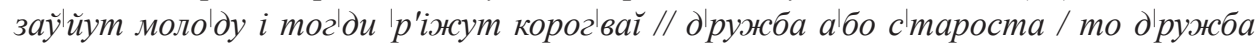
|р'іже корог'вай // тогди три йайи'а к'лали / m'реба ше ўга дати / де йайце йе // шу।кайут 'того йайи'е / та й бере по кусікови 'д'іл'ат 'кожному (Бг); так бу|ло шо

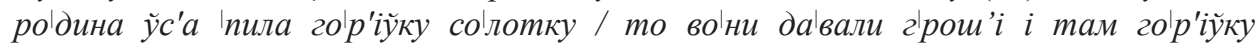
Іпили // а у нас 'того ни'ма // то не у нас 'було // у 'йенчому сел'і то так йе / то

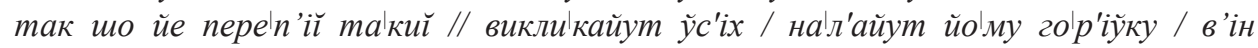




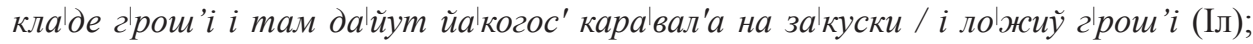
Ізараз каравал' 'p'іжут уюже / йак дацйуm подарк'i // ўже дайут по дарок на ma|p'ілку / $i{ }^{\mid}$каждому ку'сок кара'вал'а // c'тароста да йе і молода // бат"ки там викликайут |тата / 'маму / дружбу / 'каждий берре подарок // родина дайе

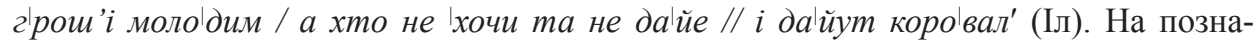
чення головного весільного хліба, призначеного для розподілу між гостями в обряді «перепою» або в повесільний день фіксуємо низку атрибутивних словоспо-

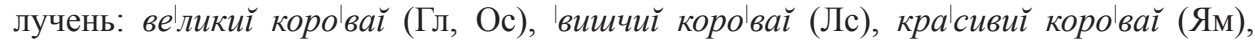

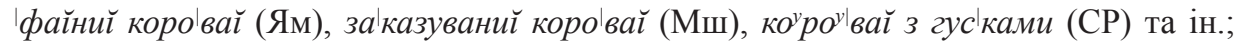

-'обрядовий хліб, призначений для розподілу між гостями в повесільний день':

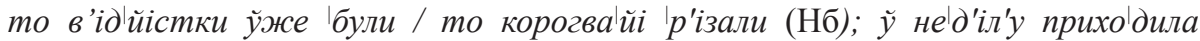
c:'войім чоло'в'іком і там ше зной 'л'уди // баггато л'у'дей не прихо дило / прихо дила до своцйейі

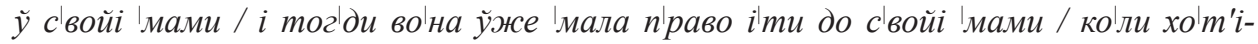

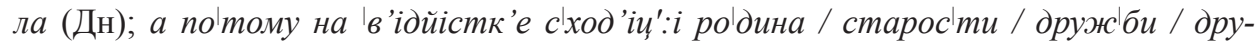
ш'ки / 'p'іжут корог'вай $i$ 'd'іл'ат той корог вай по ку'сочкови $і$ там ужже 'кождому / то каззали шо 'в’ідйістк'е // Ітоже гос'тину n’ідготойл'айут ж'ін|к'е / го'тойл'ат // 'майже иุ'iोлй ден' проходило (СНб).

Респонденти наголошують, що сучасний коровай відрізняється від того, що пекли колись: коровай перед старостоў стойоў // 'йеден коро'вай биў |перед

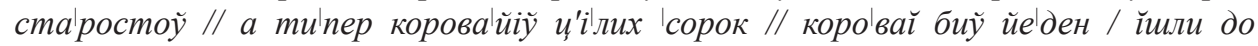
ш'л'убу / уус'о (Трл); йак йде молодий по молоду / то тодд'і коро'вай в'ін 'несе св'ій /

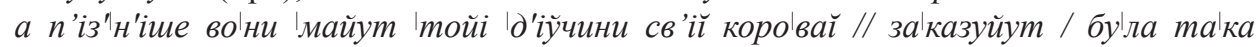
'ж’нкка коллис // та|к'i ж'ін|ки с'тарш'i пек'ли // ну / |думайете / йа'к'i то

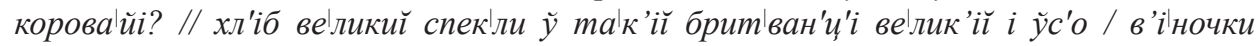
нап|хали і ўс'о // ти'пер коро'вай убб|раний хтозна-йа|кими 'лебед'ами (Крш).

Із випіканням короваю пов'язано чимало вірувань, ворожінь тощо. Зокрема в коровай запікали яйця, які наречені мали з'їсти разом зі шкаралупою, щоб мати багато здорових дітей: к'лали три йайщ'a / а'би з'нати // так дрружба май 'вир'ізати / i молофдй маў з молодойу зйісти ш:кара'лупойу / а'би |д'іти |були здо ров'i / ба'гато 'було д'і'тей // йа 'йіла ше ш:кара'лупойу / так йазик проко лола // i так тих д'ilmeй 'майеш! (Сд).

Існували й „неписані” вимоги до жінок, які брали участь в обрядодії випікан-

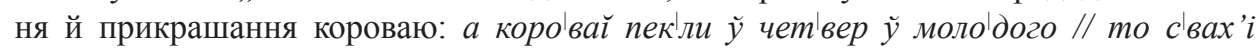
пек'ли / то ччес'н'і ж'ін|ки / по р'едн'і ж'ін|ки // такк'i / йа|к'i могіли спеччи // мо-

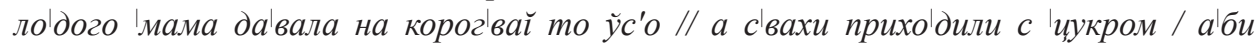

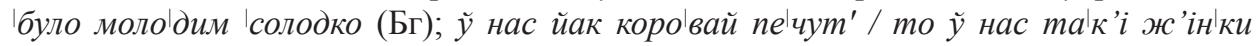
ne'чym' / молодиц'i / од|ружен'i (Рп). Пекти коровай забороняли вдовицям, розлученим жінкам, вагітним: уудовии'у не брали // вона с'а і не пххала дуже / бо то /

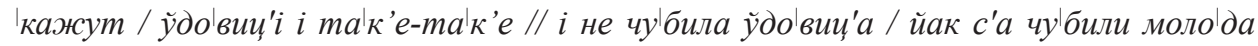

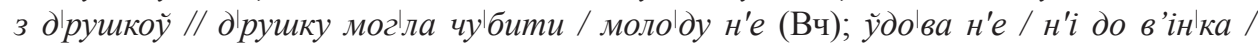
н'i до корог'вайа / н'i до 'чого (Бг); той корог'вай 'мала м'і'сити |мама зачи'нати //

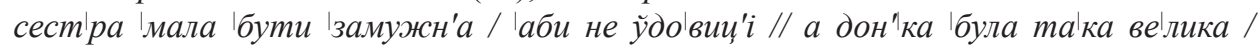
шче 'д'іучинка / сест'ра м'í|сила (Сд); - А вагітна могла місити? - н'e / бо 'm'ешко 
ж’ннкам (Сд); йак йа женила 'сина / йа закликала с'войу ку'му і ми вобидь' пек'ли // не ўдовии'а 'майе печчи коро'вай (Мж).

Цікаво, що, за бойківським звичаєм, хоча і $є$ спеціальна жінка, яка випікає коровай, проте тісто має замішувати дівчина: - Хто пік коровай? - 'кухарка печче

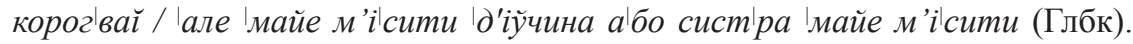

Коровай заборонено пекти в так звані пісні дні - у середу та п’ятницю:

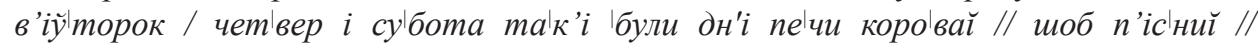

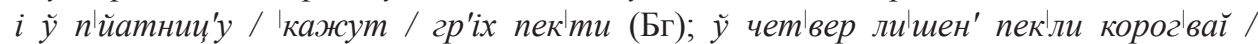

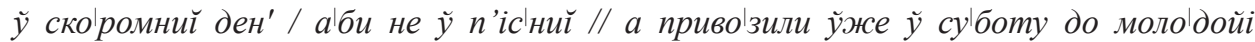
корогьвай (БГ); коро'вай пек'ли пере'важно ў чит'вер // 'середу / пйатнии'у н'е / бо

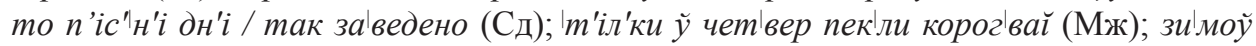

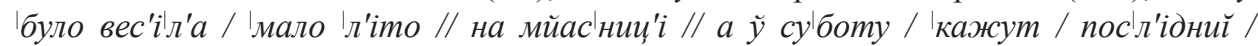

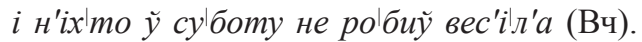

Не можна замішувати короваю в посудині, яка стоїть безпосередньо на землі:

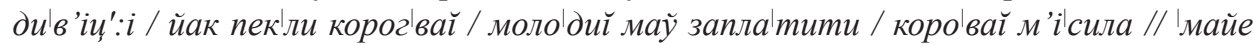

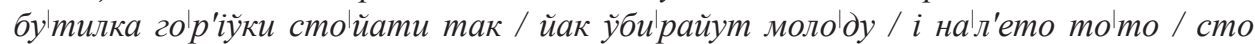

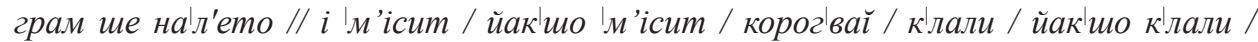

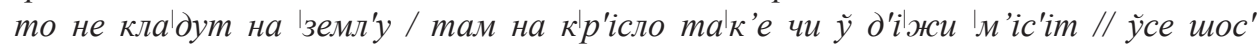
ки'дали / на 'земл'у так не к'лали (Глбк).

Випікаючи коровай, бойки спостерігали, чи вдало він випечеться, чи ні; вірили, що від цього залежало майбутнє подружнє життя наречених: йак c'a Ігарниц коровваи уцдацие / то 'кажут / моло'д'ата 'будут 'добре ьжити // $i$ 'того так / เчуйіте? / бо йа ўже ходила не раз коровайі m'i nе чи // ну 'мойім 'родич'ам / ну

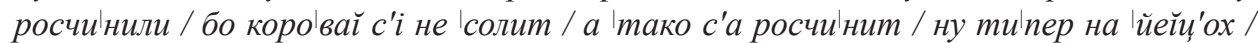

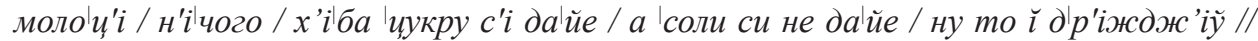
та то 'к'істо не 'кысне / та ц̆ не 'кысне / то ко'мед'ійа // ўже ў печчи затофпили / мо не та 'форма / йак на коро'вай? / ну нич // той коро'вай так / йак би му закл'а'ло / йак 'кажут // там од'н'i |кажут / з'найіте шчо? / йой / то 'буде зле / не 'будут 'жити / бо то коро'вай нич не ц̆де ўгору // зап|хали ў n’iч / коро'вайу 'к'істо упаў / 'нийакойі 'форми не 'майе // 'йолки-мо|талки / шо роббити? // д|ругий раз м'i'сити // а то ше гет / то 'було аж у Дрогобицк'ім рацион'i / то / йафке то'то се'ло бу'ло? / то'та молода 'в’іт:ам бу'ла // но мо другий раз закьликали дыругу су'с'ідку / 'каже / хо'д'іт / 'може ви короввай 'виладите / то не так / йак ти'пер коровай заказали / то мус ў молодого спеччи корофвай // ну i шо / 'умайіте? /

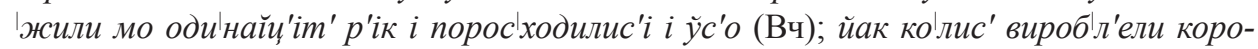
г'вай / то ууже не 'бажано 'було / а'би |д'іти |рикали / хо|дили с'y|да-ту|да / бо то не добре / м’іг 'бухнути корог'вай // - А якщо «бухнув» коровай? - то угже ка।зали / шо недобре жи'm'е 'буде молодим // старалис'а / а'би в'ін буў файнен'кий / глад|кий // 'ууже ко'сии'ами убби'рали (Бг).

У бойківських говірках фіксуємо аналітичні назви двоповер ховиц коро вай (Лк, Тр), дваповер'ховий каравал' (Іл) 'коровай, що складається зі двох хлібів, складених один на один, що, очевидно, символізувало єднання двох родів: a йa пе чу

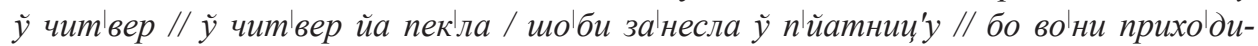
ли / х'т'іли помагати // ну йа 'мус'іла кара'вал'і 'нести уั п'йатнии'у // йа пек'ла

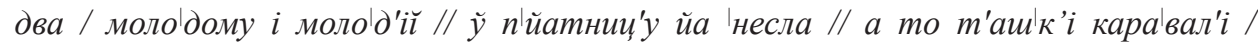


дваповерххов $i$ // тоф'і ўже йак молодойі с'а личий / а молодому n’iслали хлоп-

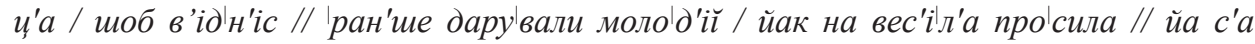
в’ід:авала / 'зам’іж виходила / 'мойа систра (Іл); 'зараз коро'вай зафказуйут /

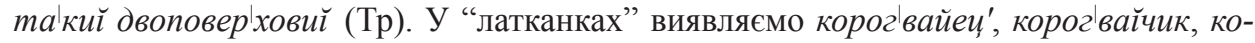
ровайко та ін.

Зі значенням 'випікати та прикрашати коровай’ в обстежених говірках фіксуємо такі назви: пек'ти, пе'чи, вип'і|кати коро(а)(г)'вац (б.н.пп.), го'товити коро'вай (Гл), 'лагодити корог'вац (Пт), роббти корог'вай (Нб), вироб'л'ети корог'вай (БГ), уббирати коровай (ВСт, Гл, Кз, Мж, Мл, СНб, Ул), прибирати коровай (Ям),

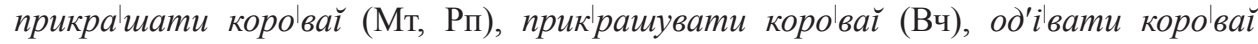
(Лc), мациети корофвай (Вч) та ін.; 'ділити коровай між усіма гостями' - d'ilлити коровацйі (Б, Гл), крайати корог'вай (Кз, Ос, Сл, Снб), 'p'ізати коро(г)'вай (Вч, Гл, Лс, Мт, Нб), розр'і'зати короввац (Рп), розри'вати куру'вай (Вл) та ін.

Лексему коро вац засвідчено як компонент стійкого словосполучення зацул'увати коровац 'розпочинати весільне святкування, танцюючи коломийку (про наречену і дружбів)': а короввай заһгул'уйут // молодий з дружбой коро'вай зацул'уйут / i там уоже / там тан'и'уйут у молодого / так забаўл'айуй':a // молод'i / $i$ ўже

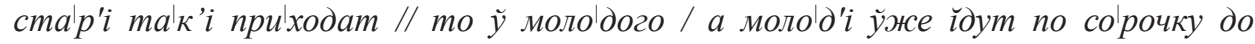
молодойі // ну і там прихход'ат ж'ін|ки / о там таке ў|c'ако // - Коровай «загу-

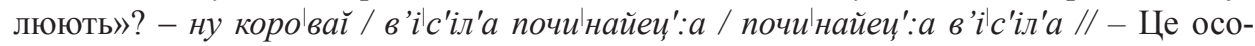

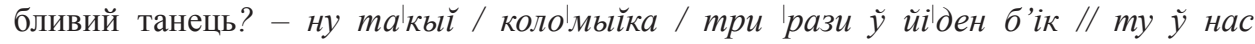

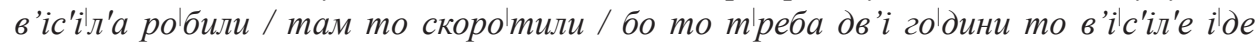
'наше // ну $і$ то во / $i$ тод'і ўже йлли по сорочку / ў|з'али соррочку / $і$ ўже там c'a погостили ў молодойі / $i$ n'iшыли ўже на коро вай (Вч); а також: заббава с коровайем 'повесільний обряд, під час якого розподіляють коровай' (Гл), корофвай на сто'л'і 'весілля' (Пт) та ін.

Спорадично в досліджуваних говірках назва коро вай функціює зі значенням 'передвесільний вечір', утворена в результаті метонімійного перенесення 'весільний хліб' $\rightarrow$ 'обряд’: а ў молодого коро вай буў / х|лопи'і по соррочку збирали / то

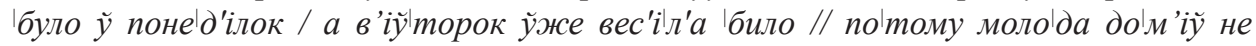

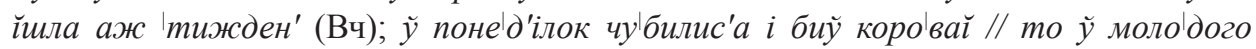
коровай / і у молодойі / йаку хто з могу моў / так му|зику си найн'али // йак дес' 'дал'ме буў молодий в’ід молодойі / то з'найіте / то ўже запро'сили |музику /

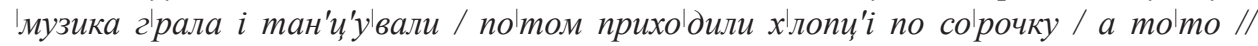
а йак тотто / а у молодого короввай буў / хлопи'i по со'рочку збирали / то 'було

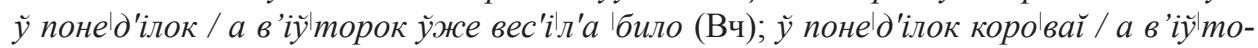

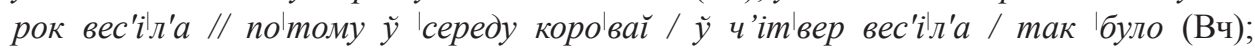
д'рушка 'каже / там прив'і'талас'а // с'лава I'cусу Хрис'ту! / с'лава 'Богу на'в’іки! // просит молофда / n'рошу йа / 'бести прийш'ли 'нис'ка на коро'вай / 'заўтра на

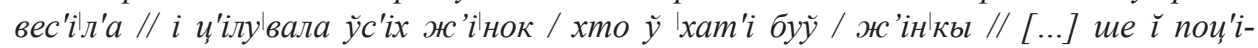
луввала чоло' 'іка йакого // а пак молода / n'росит друшка / nрошу йа / бести прийш'ли 'нис'ка на коро'вай / 'заўтра на вес'і'л'а // так про'сили // то та'ке інте'ресне 'було (Вч).

Аналізоване слово слугувало основою для творення атрибутива - назви жінки, яка несе на голові весільний хліб, а також бере участь в обряді покривання наре- 
ченої головним убором заміжньої жінки: коро(г)'вацииц'а (Мж, Тхл); демінутив коровайничка 'тс.' (Вч): - Кого запрошували за «коровайничку»? - йа|кас' з po'дини 'била / чи 'може йа'ка бра'това / чи сестра / чи йа'ка / бо коровайника вонна ужже по'том молоду пой йазувала // - «Коровайничка» пов’язувала? - коро'вайничка / бо йа са|ма 'тоже коро'вайничкоў 'була (Вч).

На західній Бойківщині зафіксовано назву чоловіка, який на голові несе для нареченої зав'язані в хустину коровай, гроші, барвінкові вінки (Мисевич 1937, 19), - підкоровайник, мотивація якого прозора.

У говірці села Головецько Старосамбірського району засвідчено дериват коровайчик в аналітичних назвах: ма|лен'киц̆ коровайчик, |менииц короввацчик, неве личкиц коро вац̆чик 'весільний хліб, який беруть до церкви або ж на якому несуть рушники'; а також: малий коровайчик на позначення хлібного виробу як викупу для хлопця, який сидів за весільним столом, не пускаючи бояр (Мисевич 1937, 25).

У деяких селах засвідчено спеціальні назви для нижньої частини короваю (по'дешва, подешва з'долу), яку часто віддавали музикантам: 'p'iзали коро'вай / a поІдешву музикантам / подешву з долу (Мт), хоча деякі інформанти наголошували на цілісності короваю; пор.: - Як називали нижню частину короваю? - н'e / mo йе сплошинй корог'вай (Кз).

Оздоблювали коровай квітами, зокрема барвінком, миртом, аспарагусом, васильками та ін., які часто покривати сухозліткою (золотистий порошок): $a \check{y}$ суботу / коли ўже |р'іжут б’ір'в'інку / 'перше ўбирайут молоду / а поттому

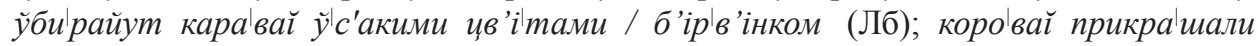

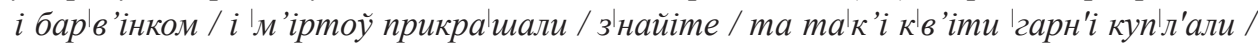
заттикували у короввай (Мт); коро'вай прикрафшайут' пере'важно к'в'ітами // йак'ио

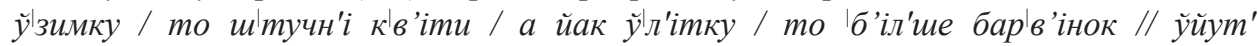

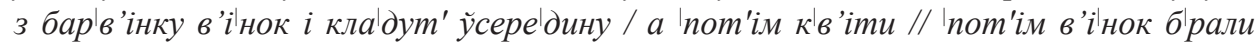
i к'лали його / шоб в 'ін ви'сушуваўс'а / ' пот'ім молодим ў 'подушку заши'вали (Рп);

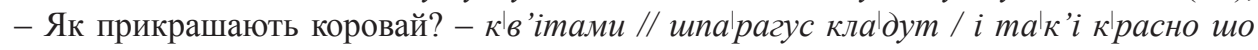
ўбирайуm (Ур).

Часто оздоблювали коровай штучними квіти, які номіновано к'я’imu (Мт),

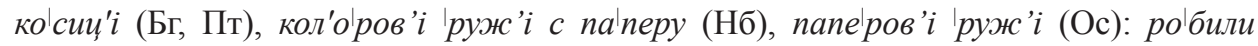
корогвацйі // от йак йа Михайлови пеклла корог'вай / ну то 'файний корогвай йа

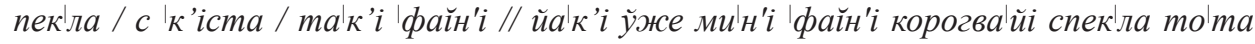
во / шо пеклла с Перег'ін'с'ка 'ж'інка // ну йа'к'i ўже 'файн'і корогвацйі спеклла

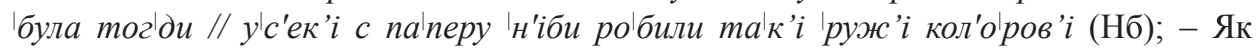
прикрашали коровай? - ну / так / йак ти'перка // 'руж'ами та'кими ви'сокими // 'тоже с паппер'іу / але не так / з'найіте / 'тон:о / йак ти'пер 'б’іл'і / лиш

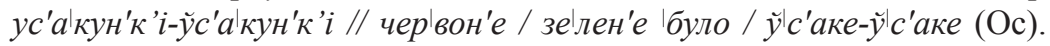

Звичай запихати в коровай застромлене на паличці яблуко зберігся від початку XX ст. (Левинський, 113); запихали ў куру'вай 'йапка // ma'к'i во поробблли патич|ки / запиххали |йапка на патич|ках // патиччок об|мотали йа|ким па|пером

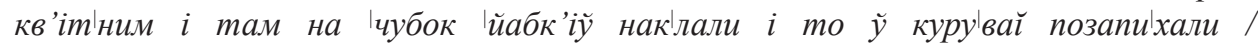
позапихали // прибрали куру'вай / бо йак са|мий? // прикра'силиси / там йа'кус' к' 'ітку зап'йели // та да'вали / 'може по пйет' / по ш'іс'm' 'йапк'iў // куру'вай не биў ве|ликий / там стойаў перед ста|ростоў (Трл) та ін. 
Коровай прикрашали, обв'язуючи:

- стрічкою ('л'ента, |бинда, с'тончка): а ж'ін|к'и та|к’i ўбирайут ко сии'у i той корогьвай так убирайут / 'л'ентойу об йезуйут / $i$ шпарагусом / к'в’ітами

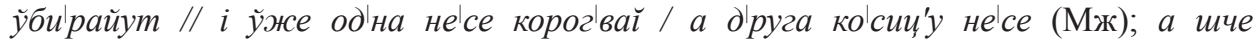
сттончкой 'атласноў ши рокой так об йезували корогьвай той наўколо / а з верха к'в 'іти // ўнизу бар' '’ночку (СНб);

- рушником: коровваи вигл'адаў / то таккойі величи'ни та|кий хл'іб / $i$ так корогьвац опе|р'ізували рушникком / $i$ так його той / $i$ прикрашували // такк’i

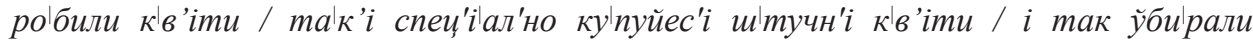

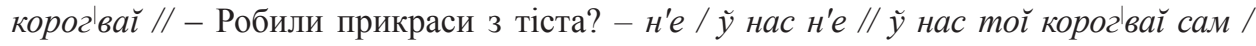
йак в'ін спечениц / то на н'ім йе прикраси // там так'i n'ташки в'іробл'айут /

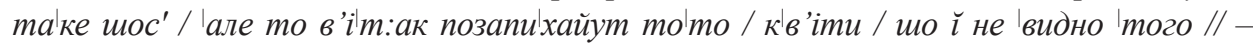
То пташки роблять з тіста і разом з короваєм запікають? - та / печут 'разом

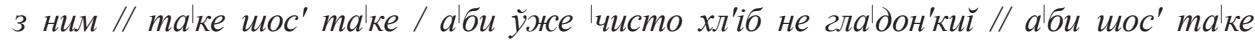
було (Кз);

- крайкою ('тканий жіночий пояс'): ще n'іуукорог'вайа так в'ід|р'ізували ку'сочок // такий ку'сок / $i$ так / бо то йе таке к'райкой / знайіте / крайки Іааўн'i // так корог'вац ко лис' крайкоу ўбрали // крайка та|ка / ну Ідаўн'а / не

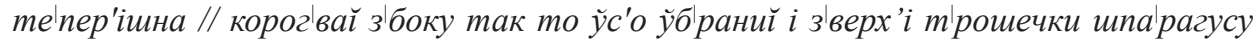
шос' Іпару к'в’іточок // i йак'шо то'ту крайку забирали / то по том / чуйіти / ли'шили ка'валок корогвацйа так четвер|тину $i$ зави вали у ту са му крайку (Глбк).

Деякі респонденти детально описують, як саме прикрашали весільний хліб: його прибрала кра'с'іво / ше там ўс'ак'i п'ташки / прибрала 'к'істом // м'і'сила

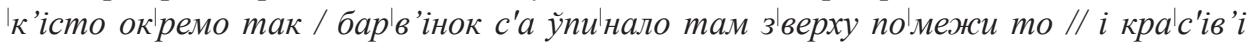
ma|к'i коровац̆і // - Що це за «пташки»? - та йа так л'ínила с 'к’icma // йа попекіла йіх на 'тому / а поттому с'ірниччок ўд'іну / бо в'ін би с'а не уттримай / Іголуби два насе редин'i коровайа / а по тому ту такк'i в'іночки красс'ів'i / ma|к'i

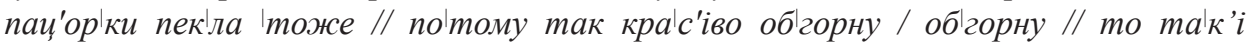
красс'ів’i коровацйі / не так / йак Ізараз спе чут / там то|ту 'косу 'виплетут $i$ усс'о

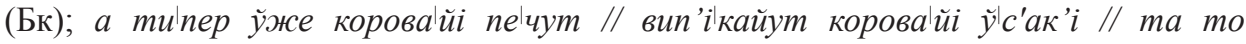

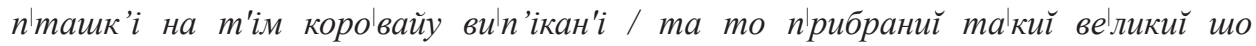
то'то (Дб); та такий во кра'сивиц / ти'пер' клаудут Іголубы / то ше запихайут /

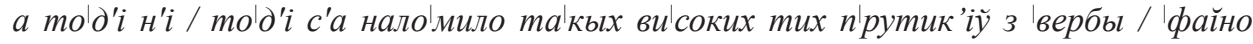

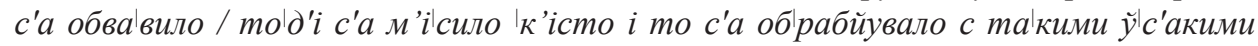
р'іжіками на той б'ік / і на той б'ік / i molmо с'а запиххало // йак уже спек'лос'а коровай / запиххалос'а у коровай $і$ усс'о (Вч); йа пе'чу карава'л'i / пок'лали на руш'ник $i$ так 'несли // а то'д'i хл'іб заўйа'зоў ў 'хустку $і$ так 'несли // йа пек'ла два каравал'i / то молодому иннакше / молод'ій иннкие // а тофму шо так йе / йа моло'д'ій пек'ла 'ангела / $і$ доўккола к'в’іти / виног'рад // а моло'дому 'кошик с иุ'в'iтами // молод'ій m|реба / шоб хорофнй йі ангел (Іл); сест ра за'м'ішувала той корог'вай / ми прийыли / пороббили кв'їточки / 'мол'ай': а / йак печчут корог'вай / а'би ўдаўс'а // 'часто роббиу су'боту ве' с'іл'а / то ў чит'вер пек'ли коро вай (Бг); ос'

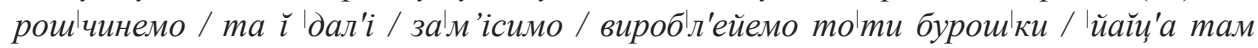
клацут / бо поттому ви р'ізуйут // то'то варен'і 'йай'і клали // а поттому / йак

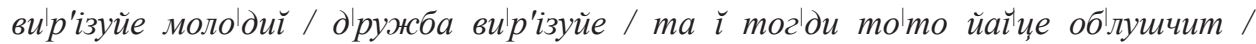




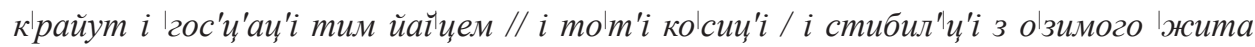

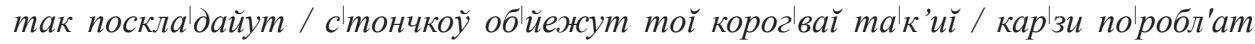

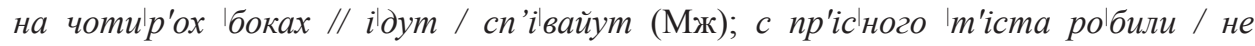
c 'того та|кого др'іж:ового / а с пр'ісіного 'm'icma // вироб/л'али Іголуби / кв’iточ|ки / листточки // обоўйас'ково 'мус'іло 'бути з:ер'на колос'ки / бо то символ'ізуьвало достаток молодойі с'ім йі (Кр); ну та то на корогвайі / йак пенут /

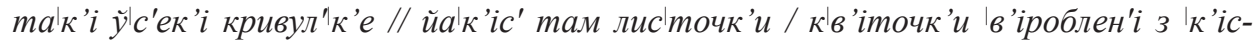
ma // то так'е роббли і там пријл'іпл'ували зверх'i / $i$ йак то с'і пек'ло / то

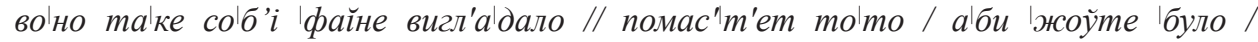
жоўт'ком тим масітили / йак печчут // а Ізараз ўже |робл'ат з 'іншого |к’іста / с кре мового (СНб).

На позначення спеціально випечених із тіста виробів для оздоби короваю фіксуємо назви: 'ангел (Іл); коло сочки (Б), коло сочки пше нии'i (К3, Лс); лист'ки (Ур), листочок (Лк), листочки('и) (Кр, СНб); к'в іти (Вч, Іл, Кз, Лс, Прг, Рп,

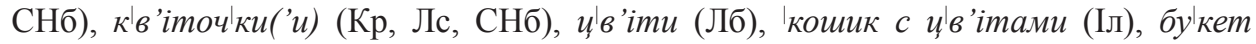
(Вч), 'руж’i (Кс); виногірад (Іл); n'maш|ки('e, ’i) (Бк, Вч, Дб, Кз, Мл, Ул, Яс, Ям), nmame' н'ата (Б, Кз, Ул, Ям), n'max'i (Вч), เглуби (Бк, Вч, Кр, Прг, Цн), เглуби два насе редин'i (Бк), 'курйата (Мл), Ілебед'i (Крш); в 'i'ночки (Бк, Крш), 'в 'інчики

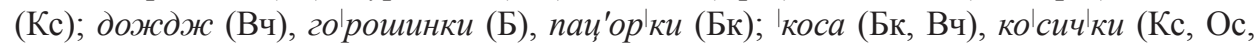
Сд); кривул"к'и (СНб) та ін.

На Бойківщині коровай часто прикрашали кількома запеченими в тісті гілочками, які називають саш|ки: коро вай пек'ли / по тому саш|ки / ну та коро вай

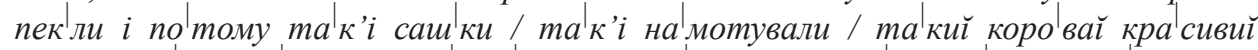

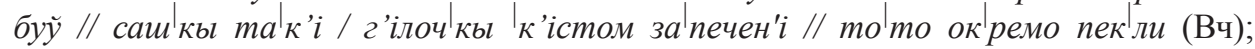

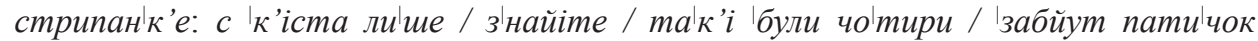

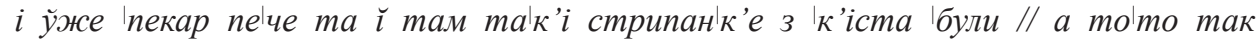

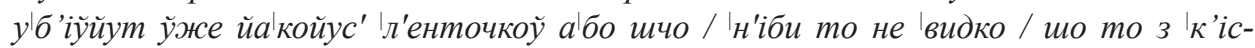

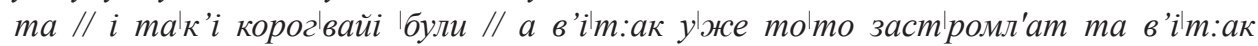
y'же 'руж'i // патич|к'е / бер'в'інок 'низом (Оc); рогач'ки, рога'тинки (Гл): убб рали

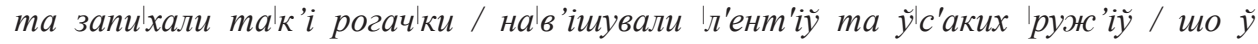

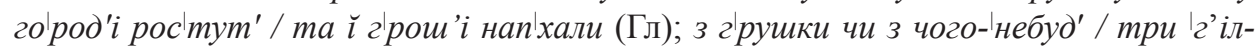

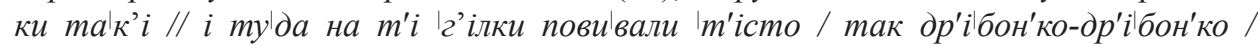
др'і|бон'ко та|кими рога|тинками (Гл); 'к'ічки: коро'вай пек'ли / зама йели 'к'ічками

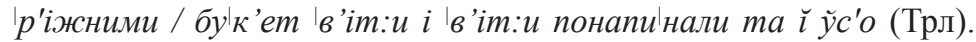

Обрядовий контекст використання весільного хліба - короваю - в обстежених бойківських говірках демонструє розгалужену семантичну структуру лексеми, виявляє тенденцію до творення словотвірних дериватів з обрядовим значенням (коро'вайниц'а. підкоровайник та ін.), семантичних дериватів (коровай 'обрядовий хліб', коро'вай 'передвесільний вечір' та ін.), демінутивів (коро'вайничка, коро вайко та ін.), а також компонування сталих словосполучень (загул'увати коровац, заббава с коровацием та ін.). Аналізоване слово слугує основою творення аналітичних назв (двоповерххоиц короввац, од'ilвати короввац та ін.) та засвідчує варіативність на різних мовних рівнях. 
Мережа обстежених населених пунктів

Б - Бабино Старосамбірського р-ну Львівської обл.

Бг - Богрівка Богородчанського р-ну Івано-Франківської обл.

Бгт - Багнувате Турківського р-ну Львівської обл.

Бк - Боберка Турківського р-ну Львівської обл.

Бкв - Буковець Міжгірського р-ну Закарпатської обл.

Бл - Біласовиця Воловецького р-ну Закарпатської обл.

Бн - Бачина Старосамбірського р-ну Львівської обл.

Бнв - Беньова Турківського р-ну Львівської обл.

Бр - Бориня Турківського р-ну Львівської обл.

Бс - Бусовисько Старосамбірського р-ну Львівської обл.

Бт - Бітля Турківського р-ну Львівської обл.

Бч - Біличі Старосамбірського р-ну Львівської обл.

В - Воля Старосамбірського р-ну Львівської обл.

ВБ - Верхій Бистрий Міжгірського р-ну Закарпатської обл.

ВВ - Верхнє Висоцьке Турківського р-ну Львівської обл.

ВВл - Велика Волосянка Старосамбірського р-ну Львівської обл.

ВВт - смт Верхні Ворота Міжгірського р-ну Закарпатської обл.

Вл - Волосянка Сколівського р-ну Львівської обл.

Влв - смт Воловець Закарпатської обл.

Влс - Волосянка Великоберезнянського р-ну Закарпатської обл.

ВЛн - Велика Лінина Старосамбірського р-ну Львівської обл.

Влж - Верхній Лужок Старосамбірського р-ну Львівської обл.

Влк - Великосілля Старосамбірського р-ну Львівської обл.

Влш - Волошиново Старосамбірського р-ну Львівської обл.

Вн - Винники Дрогобицького р-ну Львівської обл.

ВC - Верхній Студений Міжгірський р-н Закарпатської обл.

ВСт - Верхня Стинава Сколівського р-ну Львівської обл.

ВСш - Велика Сушиця Старосамбірського р-ну Львівської обл.

Вч - Вовче Турківського р-ну Львівської обл.

Вш - Вишків Долинського р-ну Івано-Франківської обл.

ВЯб - Верхня Яблунька Турківського р-ну Львівської обл.

Гв - Гвоздець Старосамбірськогоо р-ну Львівської обл.

Гк - Галівка Старосамбірського р-ну Львівської обл.

Гкл - Гукливий Воловецького р-ну Закарпатської обл.

Гл - Головецько Старосамбірського р-ну Львівської обл.

Глб - Глибока Старосамбірського р-ну Львівської обл.

Глбк - Глибоке Богородчанського р-ну Івано-Франківської обл.

Гр - Грозьово (Грозова) Старосамбірського р-ну Львівської обл.

Грб - Грабовець Сколівського р-ну Львівської обл.

Гт - Голятин Міжгірського р-ну Закарпатської обл.

Д - Дидьова Турківського р-ну Львівської обл.

Дб - Доброгостів Дрогобицького р-ну Львівської обл.

Дз - Дзвиняч Богордчанського р-ну Івано-Франківської обл..

Дл - м. Долина Івано-Франківської обл. 
Дн - Дністрик Старосамбірського р-ну Львівської обл.

Ж - Жукотин Турківського р-ну Львівської обл.

Жд - Жденієво Воловецького р-ну Львівської обл.

Жп - Жупани Сколівського р-ну Львівської обл.

Зб - Зубриця Турківського р-ну Львівської обл.

Зв - Завадка Сколівського р-ну Львівської обл.

Звд - Завадка Воловецького р-ну Закарпатської обл.

I - Ісаїв Турківського р-ну Львівської обл.

Із - Ізки Міжгірського р-ну Закарпатської обл.

Іл - Ільник Турківського р-ну Львівської обл.

Кз - Кузьминець Рожнятівського р-ну Івано-Франківської обл.

Кзв - Козеве Сколівського р-ну Львівської обл.

Кзк - Козаківка Долинського р-ну Івано-Франківської обл.

Кк - Кривка Турківського р-ну Львівської обл.

Кл - Келечин Міжгірського р-ну Закарпатської обл.

Км - Комарники Турківського р-ну Львівської обл.

Кр - Коростів Сколівського р-ну Львівської обл.

Крн - Кринтята Турківського р-ну Львівської обл.

Крш - Крушельниця Сколівського р-ну Львівської обл.

Кс - Красне Рожнятівського р-ну Львівської обл.

Кт - Катино Старосамбірського р-ну Львівської обл.

Кч - Корчин Сколівського р-ну Львівської обл.

Л - Лолин Долинського р-ну Івано-Франківської обл.

Лб - Либохора Турківського р-ну Львівської обл.

Лбх - Лібухова Старосамбірського р-ну Львівської обл.

Лв - Лавочне Сколівського р-ну Львівської обл.

Лг - Луги Рожнятівського р-ну Івано-Франківської обл.

Лз - Лозянський Міжгірського р-ну Львівської обл.

Лк - Луквиця Богородчанського р-ну Івано-Франківської обл.

Лм - Лімна Турківського р-ну Львівської обл.

Лк - Лісковець Міжгірського р-ну Закарпатської обл.

Лп - Лопушанка Турківського р-ну Львівської обл.

Лпв - Липовиця Рожнятівського р-ну Львівської обл.

Лпш - Лопушне Міжгірського р-ну Закарпатської обл.

Лс - Лосинець Турківського р-ну Львівської обл.

Лт - Латірка Воловецького р-ну Львівської обл.

Лц - Лецівка Рожнятівського району Івано-Франківської обл.

Мжг - смт Міжгір'я Закарпатської обл.

Мж - Міжгір'я Богородчанського р-ну Івано-Франківської обл.

Мл - Мельничне Турківського р-ну Львівської обл.

Мр - Муроване Старосамбірського р-ну Львівської обл.

Мт - Матків Турківського р-ну Львівської обл.

Мх - Махнівець Старосамбірського р-ну Львівської обл.

Мхн - Мохнате Турківського р-ну Львівської обл.

Мш - Мшанець Старосамбірського р-ну Львівської обл. 
Н - Нижнє Самбірського р-ну Львівської обл.

Нб - Небилів Рожнятівського р-ну Івано-Франківської обл.

Нв - Новоселиця Міжгірського р-ну Закарпатської обл.

НГс - Нижнє Гусне Турківського р-ну Львівської обл.

Нд - Недільна Старосамбірського р-ну Львівської обл.

НРж - Нижня Рожанка Сколівського р-ну Львівської обл.

Нч - Нагуєвичі Дрогобицького р-ну Львівської обл.

НЯб - Нижня Яблунька Турківського р-ну Львівської обл.

Оп - Опорець Сколівського р-ну Львівської обл.

Ор - Орів Сколівського р-ну Львівської обл.

Орв - Орявчик Сколівського р-ну Львівської обл.

Ос - Осмолода Рожнятівського р-ну Івано-Франківської обл.

Пг - Погар Сколівського р-ну Львівської обл.

Пд - Підгородці Сколівського р-ну Львівської обл.

Пдс - Підсухе Дрогобицького р-ну Львівської обл.

Пк - Побук Сколівського р-ну Львівської обл.

Пл - Плав'я Сколівського р-ну Львівської обл.

Пр - Присліп Турківського р-ну Львівської обл.

Прг - смт Перегінське Рожнятівського р-ну Івано-Франківської обл.

Прс - Присліп Міжгірського р-ну Закарпатської обл.

Пт - Петранка Рожнятівського р-ну Івано-Франківської обл.

Рз - Розлуч Турківського р-ну Львівської обл.

Рк - Рекіти Між гірського р-ну Львівської обл.

Рп - Ріп'яна Старосамбірського р-ну Львівської обл.

Рпн - Репинне Між гірського р-ну Закарпатської обл.

Рс - Росохи Старосамбірського р-ну Львівської обл.

Рч - Річка Міжгірського р-ну Закарпатської обл.

Св - Свидник Турківського р-ну Львівської обл.

Сд - Саджава Богородчанського р-ну Івано-Франківської обл.

Сбч - Стрільбище Старосамбірського р-ну Львівської обл.

Ск - Солуків Долинського р-ну Івано-Франківської обл.

Скл - м. Сколе Сколівського р-ну Львівської обл.

Скт - Скотарське Воловецького р-ну Закарпатської обл.

Сл - Сливки Рожнятівського р-ну Івано-Франківської обл.

Слв - смт Славське Сколівського р-ну Львівської обл.

См - Сойми Міжгірського р-ну Закарпатської обл.

Сн - Сенечів Долинського р-ну Івано-Франківської обл.

СНб - Слобода-Небилівська Рожнятівського р-ну Івано-Франківської обл.

CP - Стара Ропа Старосамбірського р-ну Львівської обл.

CC - м. Старий Самбір Львівської обл.

Ств - Старява Старосмабірського р-ну Львівської обл.

Стр - Стрілки Старосамбірського р-ну Львівської обл.

Стрг - Стригальня Міжгірського р-ну Закарпатської обл.

$\mathrm{Cx}$ - Східниця Дрогобицького р-ну Львівської обл.

Схд - Суходіл Рожнятівського р-ну Івано-Франківської обл. 
Сш - Страшевичі Старосамбірського р-ну Львівської обл.

Сшц - Сушиця Старосамбірського р-ну Львівської обл.

Т - Тур'є Старосамбірського р-ну Львівської обл.

Тв - Тершів Старосамбірського р-ну Львівської обл.

Тн - Торунь Між гірського р-ну Львівської обл.

Тр - Труханів Сколівського р-ну Львівської обл.

Трл - Терло Старосамбірського р-ну Львівської обл.

Тс - Тисовиця Старосамбірського р-ну Львівської обл.

Тсв - Тисів Долинського р-ну Івано-Франківської обл.

Тх - Тухолька Сколівського р-ну Львівської обл.

Тхл - Тухля Сколівського р-ну Львівської обл.

Тш - Тишівниця Сколівського р-ну Львівської обл.

Тшв - Тишів Воловецького р-ну Закарпатської обл.

Тшк - Тюшка Міжгірського р-ну Закарпатської обл.

Уж - Уріж Дрогобицького р-ну Львівської обл.

Ул - Уличне Дрогобицького р-ну Львівської обл.

Ур - Урич Сколівського р-ну Львівської обл.

Хв - Хащів Турківського р-ну Львівської обл.

Ч - Чаплі Старосамбірського р-ну Львівської обл.

Цн - Цінева Рожнятівського р-ну Львівської обл.

Шм - Шум'яч Турківського р-ну Львівської обл.

Шн - Шандровець Турківського р-ну Львівської обл.

Яб - Яблунів Турківського р-ну Львівської обл.

Яв - Явора Турківського р-ну Львівської обл.

ЯЗм - Ясениця-Замкова Старосамбірського р-ну Львівської обл.

Ял - Ялинкувате Сколівського р-ну Львівської обл.

Ям - Ямельниця Сколівського р-ну Львівської обл.

Яс - Ясень Рожнятівського р-ну Івано-Франківської обл.

ЯСл - Ясениця-Сільна Дрогобицького р-ну Львівської обл.

Ясн - Ясениця Турківського р-ну Львівської обл.

\section{Література}

Кобільник В. (2009), Матеріяльна культура села Жукотин Турчанського повіту. Ч. III. Одяг, [в:] Літопис Бойківщини. Перевидання часопису, вип. 3, ч. 7-9 за 19361937 pp., упоряд., підг. до пуб., заг. ред. Р. Данчин [Kobilnyk V., Materiialna kultura sela Zhukotyn Turchanskoho povitu. Ch. Sh. Obiah, [v:] Litopys Boikivshchyny. Perevydannia chasopysu, vyp. 3, ch. 7-9 za 1936-1937 rr. uporiad. pidg. do pub., zag. red. R. Danchyn], Львів, с. 228-243.

Левинський, Левинський В. Бойківське весїле в Доброгостові (Дрогобицького повіта), [в:] Матеріали до украӥнсько-руської етнологї, т. X [Levynskyi V., Boikivske vesilie v Dobrohostovi (Drohobitskoho povita), [v:] Materialy do ukrainsko-ruskoi etnolohii], Львів, 1908 , c. $101-120$. 
Мисевич О. (1937), Український весільний обряд у Бойківщчині [Mysevych O., Ukrainskyi vesilnyi obriad и Boikivshchyni], Львів.

СУМ, Словник української мови, т. I-X, ред. І. Білодід та ін.[Slovnyk ukrainskoi movy, t, I-X, red. I. Bilodid ta in.], Київ 1971-1981.

Хібеба Н. (2018а), Номінація весільного хліба в бойківських говірках, [в:] Вісник Львівського університету. Серія філологічна, вип. 68 [Khibeba N., Nominaciia vesilnoho khliba $v$ boikivskykh hovirkakh, [v:] Visnyk Lvivskoho universytetu. Seriia filolohichna, vip. 68], Львів, с. 240-249.

Хібеба Н. (2018b), Обрядова функиія весільного печива та його мовна проекція в бойківських говірках, [в:] Діалектологічні студї. 11. Слово - словник - корпус, відп. ред. П. Гриценко, Н. Хобзей [Khibeba N., Obriadova funktsiia vesilnoho pechyva ta ioho movna proektsiia v boikivskikh hovirkakh, [v:] Dalektolohichni studii. 11. Slovo - slovnyk - korpus, red. P. Hrytsenko, N. Khobzei], Львів, с. 152-166. 
